\author{
A.K. Kabdybay, ${ }^{1, *}$, N.D. Kenzhebekov ${ }^{2}$, D.I.Syzdykova ${ }^{3}$, D.N. Ulybyshev ${ }^{4}$, Ye.B. Zhailauov ${ }^{5}$ \\ ${ }^{1,3,5}$ Karagandy University of the name of academician E.A. Buketov, Kazakhstan, \\ ${ }^{2}$ Karaganda Economic University of Kazpotrebsoyuz, Kazakhstan, \\ ${ }^{4}$ Plekhanov Russian Economic University, Russian Federation, ${ }_{1,2,3,5}$ RATIONAL SOLUTION LLP, Kazakhstan,

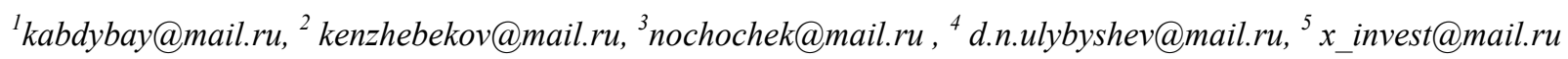 \\ ${ }^{1}$ https://orcid.org/0000-0002-3149-9727, ${ }^{2}$ https://orcid.org/0000-0002-1292-8653, ${ }^{3}$ http://orcid.org/0000-0001-6547- \\ 9639, ${ }^{4}$ https://orcid.org/0000-0003-3534-5992, ${ }^{5}$ https://orcid.org/0000-0002-0609-6256 \\ ${ }^{1}$ Scopus Author ID: 57209533934, ${ }^{3}$ Scopus Author ID:1598245623139, \\ ${ }^{4}$ Scopus Author ID: 57201644794, ${ }^{5}$ Scopus Author ID: 57194586056 \\ ${ }^{1}$ Researcher ID: AAF-6871-2020, ${ }^{3}$ Researcher ID: AAD-3713-2020, \\ ${ }^{4}$ Researcher ID: AAA-8631-2019, ${ }^{5}$ Researcher ID: AAF-6871-2020
}

\title{
Directions of the state policy of technological development of the mining and metallurgical complex of Kazakhstan
}

\begin{abstract}
Object: The purpose of the research is to determine the priorities of Kazakhstan's technological policy aimed at modernizing and developing high-tech production in the domestic metallurgical complex.

Methods: The research used the method of system analysis, the method of collecting secondary information, the method of structuring goals.

Results: As the main results, it is necessary to highlight the assessment of the state and definition of the role of the metallurgical complex in the economic potential of the republic, based on the definition of development priorities, recommendations were given on the structural and technological reform of metallurgy in Kazakhstan.

It should be noted that with a high share of the export component in the sales structure of metallurgical enterprises and a constant shortage of metal products in the domestic market, domestic enterprises do not have a strong motivation to expand the range and master new materials.

Conclusions: In our opinion, breakthrough technologies from the existing innovation system should not be expected in the near future, the transfer of technologies is difficult due to existing counterparties: foreign investments of large transnational corporations are aimed at developing the raw material base and attracting mining capacities. In this regard, state policy should be aimed primarily at the complexity and rationality of the use of natural resources.

To ensure a more complete use of the production capacities of the existing enterprises, one of the ways to replenish the retired capacities is to bring into operation poor off-balance ores, as well as re-development of previously worked out areas, reactivation of protective pillars and recovery of ores written off as losses.
\end{abstract}

Keywords mining and metallurgical complex, metallurgical treatment, modernization, rational use of mineral resources, technological policy, competitiveness of the metallurgical industry, technological structure.

\section{Introduction}

The modern development of the world metallurgy is characterized by radical changes associated with a sharp acceleration of scientific and technological progress in the field of production technologies and the quality of manufactured products. The driving force of this process is the innovative nature of capital reproduction, based on scientific achievements, rapid development of new technologies for the production of modern competitive metal products. Kazakhstan needs to develop high technologies in the domestic manufacturing industry, the main share of which is occupied by the export-oriented metallurgical complex.

At the present stage of development in the metallurgical complex of Kazakhstan, there are important issues of determining ways to increase and expand the production of a new technological order. Kazakhstan's metallurgy has always been the flagship of the country's development and the foundation for the well-being of its citizens - it is an industry that can bring income to the budget in foreign currency, comparable to the profit from oil production (Breunig et.al, 2016).

Today, Kazakhstan's metallurgical industry operates in the context of global competition on the world market.

In the context of an open economy and integration into the international division of labor, an active state policy aimed at stimulating progressive structural shifts towards the production of modern metal prod-

\footnotetext{
"Corresponding author.

E-mail address: kabdybay@mail.ru
} 
ucts with high added value, improving the efficiency and competitiveness of all sectors of the economy cannot be solved in a short time and will be a priority in the medium and long term. In this regard, in our opinion, it is necessary to gradually implement the strategy for the modernization of metallurgy, since its implementation period is several years.

As the main hypothesis, it is supposed to determine the main state tools for the modernization of the metallurgical industry in Kazakhstan by determining the factors of the industry's competitiveness in the modern economy.

\section{Literature Review}

In modern economic theory, the neoclassical paradigm still prevails; or, in any case, neoclassical views should be recognized as the most widespread. I.e., most of the factors of economic growth are not the share of marginal productivity of factors (primarily labor and capital), but the share of «unidentifiable factors»the contribution of the increase in the total productivity of factors, mainly due to scientific and technological progress.

At the present stage, the neoclassical school uses a different apparatus for studying the influence of «unidentifiable factors» on labor productivity growth. The most scientifically based results are the works of researchers - «evolutionists», their approach to the development of the economy is the development of processes of various durations, cyclical fluctuations. Accordingly, the center of attention are the big cycles of conjuncture (Kondratieff cycles): there are five such cycles and five main technological structures.

This description is quite in line with the theory of economic development of J. Schumpeter, as well as the explanation of cyclical fluctuations in interest rates, which was given in his classic work by N.D. Kondratieff himself (although he linked these cyclical changes rather with changes in the value of the most longterm (passive) part of fixed capital). Naturally, this explanation applies only to the market economy (Byun et al., 2017).

The main attention is paid to the study of real processes, which are determined by:

- the core of the technological paradigm (industry composition);

- its key factor (basic innovation);

- the emerging core of the new order;

- technology-leading countries;

- developed (catching up with leaders) countries;

- advantages of this technological structure in comparison with the previous one;

- economic regulation regimes in leading countries;

- international economic regulation regimes;

- main economic institutions;

- organization of innovative activity in leading countries.

In the growth phase of the dominant technological order, which is characterized by stable growth rates of its constituent industries and the entire economy as a whole, the interest rate remains stable, reflecting stable conditions for the reproduction of social capital.

As the dominant technological order approaches the limits of growth and the rate of profit in its constituent industries decreases, the marginal efficiency of capital investments rapidly decreases. Along with the decline in the expected return on investment, the interest rate falls. At the same time, production and the new technological order remain low profitable and do not attract the attention of business entities. As a result, the capital freed from the industries of the dominant technological order does not find application, despite the decrease in the interest rate. The replacement of technological orders is mediated by a more or less prolonged investment pause, during which the real interest rate may even become negative. With the formation of the reproduction contour of a new technological order and an increase in the efficiency of its constituent industries, both as a result of changes in the system of economic assessments and their technological improvement, accompanied by the formation of new consumer preferences and a corresponding change in the structure of demand, the interest rate increases sharply. In the course of these fluctuations, speculative operations intensify and a significant part of the capital associated in the production of replaced technological capital is depreciated (ElGindi, 2017).

Currently, in Kazakhstan, we can talk about the functioning of four technological orders and weak attempts of the fifth technological order. The spread of technological orders in our republic was much slower than in the USA, Japan, Germany and other foreign countries, as well as Russia. 
The priority development of the fifth technological order in the world economy and the emergence of the sixth technological order make it possible to talk about a new quality of economic growth, which is gradually taking the central place in the world economy.

Summarizing the conditions for the development of metallurgy in Kazakhstan and the priorities for the development of the economy of Kazakhstan, in our opinion, scientific research aimed at the formation of a «new economy» and the innovative development of its leading industries are of great relevance. The experience of leading industrial countries has shown that such trends are largely due to a change in the economic role of innovation, the pace of directions and mechanisms for implementing innovation processes (Satybaldin, 2016). Empirical analysis of trends and drivers of economic growth in OECD countries suggests that innovation has become «a key driver of more productive economic growth». This is confirmed by: a sharp increase in such indicators as the multifactor index of labor productivity, reflecting the efficiency of the productive use of labor and capital; the increasing impact of technological progress embodied in investment goods and knowledge embodied in skilled labor.

Structural shifts that involve changes in inter-industry, intra-industry, and macro-economic proportions are aimed at:

- decrease in the share of the primary sector of the economy due to an increase in the share of manufacturing products;

- modernization of production, including technical and technological, improving the competitiveness of products;

- improving the efficient and rational use of natural resources;

- increasing the level of the republic's export potential through the production of science-intensive high-tech products;

- creating conditions for the development of innovative activities; 2017).

- promotion of further development of small and medium-sized businesses (Byun, 2017; Lenort et al.,

In a study conducted by the UN, modernization and technological change should affect job creation and income distribution. Ideally, the technologies introduced should create new jobs and at the same time improve the distribution of income in society (Massa, 2015).

If we turn to the specifics of technological changes in the metallurgical industry, researchers point to a number of influencing factors (Wang et al., 2016, Gajdzik, 2019; Sung Park et al., 2019):

1) Enlargement to the level of a global player. In this case, the value allows you to save money due to the volume of purchases from suppliers of raw materials and strengthen your position in negotiations with consumers of steel products. First of all, Chinese companies are seen as new global players.

2) Vertical integration to raw materials processing, since the availability of raw materials continues to be vital, and a small or medium-sized company will not be able to buy raw materials on the free market at an affordable price.

3) Production of niche products with high added value: rails, stainless steel, auto sheet and other types of special steels.

Quite a lot of attention in recent studies of technological modernization is paid to environmentally friendly industries (Jiaa et al., 2017; Dotsenko et al., 2019).

Despite the long study of this problem, the disposal and processing of industrial waste is still not carried out at the proper level. The severity of the problem, despite a sufficient number of solutions, is determined by the increase in the level of formation and accumulation of industrial waste. The efforts of foreign countries are primarily aimed at preventing and minimizing waste generation, and then at recycling, recycling and developing effective methods for final processing, neutralization and final disposal, and disposal only of waste that does not pollute the environment. All these measures undoubtedly reduce the level of negative impact of industrial waste on nature, but do not solve the problem of their progressive accumulation in the environment and, consequently, the increasing danger of harmful substances entering the biosphere under the influence of man-made and natural processes. The variety of products that can be obtained and consumed without waste with the modern development of science and technology is very limited, and can be achieved only in a number of technological chains and only by highly profitable industries.

\section{Methods}

In Kazakhstan, the actual minerals and products of their primary processing (including metallurgical processing) make up about $80 \%$ of GDP. This determines the great importance of the mineral resource complex and its specific role in the formation of industrial policy. 
In this regard, the methodological basis of this study is the concept of Ecologically sustainable industrial development (ESID).

In relation to manufacturing processes, EFM means reducing material and energy costs, eliminating toxic raw materials from the manufacturing process, and reducing the amount and level of toxicity of all emissions and waste before they leave the production process.

When evaluating the "product life cycle», attention is drawn to the fact that in the four - stage cycle scheme, only one stage - «production» - refers to an industry problem. All others are cross-industry tasks. Thus, an event that is useful for the industry will not necessarily be beneficial for the national economy as a whole.

At the same time, some methods of production estimation have been developed in developed countries. In these countries, the technology that has not passed the examination for compliance with the criteria of «environmentally friendly manufacturing» has no prospects in the future. When licensing, experts compare the technology offered for use in production with BAT («Best available technology») - the best available technology, as well as BPT («Best possible technology») - the best possible technology. BAT in contrast to BPT has been implemented in practice, and it is its performance that is compared with the characteristics of the proposed technology.

The emergence of a new class of models of economic growth with endogenous technological progress has caused a noticeable surge of interest in the problems of economic dynamics. As shown by the endogenous growth models published to date, these most universal levers can be:

- development of innovative entrepreneurship and venture financing mechanisms for innovations;

- effective tax regulation;

- wider use of technological transfer opportunities on a national and international scale.

\section{Results}

Over the past years, economic growth in Kazakhstan has been largely achieved due to the raw materials industries, but, unfortunately, it has little to do with a qualitative change in the structure of the domestic metallurgical industry, products and services.

Currently, the metallurgy of Kazakhstan is characterized by the third, partly the fourth treatment. This situation determines the high resource intensity of GDP, which in turn is associated with the technological diversity of the economy.

The metallurgical complex of the republic unites large corporations for the production of ferrous and non-ferrous metals with a developed infrastructure (" Arcelor Mittal Temirtau» JSC, "SSGPO» JSC, TNC «Kazchrome », «Kazakhmys Corporation» LLP, «Kazzinc» JSC, «Aluminum of Kazakhstan» JSC, etc.) (Table 1) (World Steel in Figures, 2020).

Table 1. Production of the main types of metallurgical industry in Kazakhstan

\begin{tabular}{|c|c|c|c|c|c|c|c|c|c|c|}
\hline & 2010 & 2011 & 2012 & 2013 & 2014 & 2015 & 2016 & 2017 & 2018 & 2019 \\
\hline Ferroalloys, tons & $\begin{array}{c}1701 \\
790\end{array}$ & $\begin{array}{c}1668 \\
689\end{array}$ & $\begin{array}{c}1724 \\
065\end{array}$ & $\begin{array}{c}1706 \\
931\end{array}$ & $\begin{array}{c}1715 \\
137\end{array}$ & $\begin{array}{c}1741 \\
920\end{array}$ & $\begin{array}{c}1826 \\
340\end{array}$ & $\begin{array}{c}1934 \\
774\end{array}$ & $\begin{array}{c}2088 \\
638\end{array}$ & $\begin{array}{c}2175 \\
767\end{array}$ \\
\hline $\begin{array}{l}\text { Tin white and } \\
\text { rolled sheet } \\
\text { tinned, tons }\end{array}$ & 210376 & 206744 & 160507 & 85775 & 76717 & 94614 & 86111 & no data & no data & 60264 \\
\hline $\begin{array}{l}\text { Raw and semi- } \\
\text { processed gold or } \\
\text { in the form of } \\
\text { powder, } \mathrm{kg}\end{array}$ & 30272 & 36846 & 39903 & 42552 & 50339 & 63614 & 74737 & 85339 & 100288 & 106559 \\
\hline $\begin{array}{l}\text { Untreated alumi- } \\
\text { num; aluminum } \\
\text { oxide, tons }\end{array}$ & $\begin{array}{c}1867 \\
309\end{array}$ & $\begin{array}{c}1919 \\
158\end{array}$ & $\begin{array}{c}1760 \\
412\end{array}$ & $\begin{array}{c}1840 \\
159\end{array}$ & $\begin{array}{c}1628 \\
252\end{array}$ & $\begin{array}{c}1670 \\
215\end{array}$ & $\begin{array}{c}1745 \\
801\end{array}$ & $\begin{array}{c}1771 \\
697\end{array}$ & $\begin{array}{c}1751 \\
472\end{array}$ & $\begin{array}{c}1671 \\
129\end{array}$ \\
\hline $\begin{array}{l}\text { Unwrought lead, } \\
\text { tons }\end{array}$ & 103400 & 111518 & 88099 & 91072 & 127064 & 120108 & 134192 & 149129 & 152767 & 132669 \\
\hline $\begin{array}{l}\text { Unprocessed } \\
\text { zinc, tons }\end{array}$ & 318858 & 319847 & 319847 & 320150 & 324946 & 323848 & 325820 & 331018 & 317965 & 318399 \\
\hline $\begin{array}{l}\text { Copper, refined, } \\
\text { unprocessed, } \\
\text { unalloyed, tons }\end{array}$ & 323368 & 338524 & 367161 & 352061 & 294808 & 394641 & 408435 & 426191 & 438115 & 472327 \\
\hline
\end{tabular}


As can be seen from the table, only tin and sheet metal of «Arcelor Mittal Temirtau» JSC technologically belongs to the 4th treatment, the rest of the metals are exported in ingots and slabs, 2nd, maximum 3rd treatment. In addition, the difficult situation on the world ferrous metals market causes an annual decline in production volumes.

At the same time, trends in the production of non-ferrous metals show either growth or production volumes have not changed for ten years.

It should be noted that with all the variety and large volumes of metal products, the production of finished metal products is characterized by insignificant volumes and scarcity of assortment. Such trends in the development of the metallurgical industry in Kazakhstan have attracted the fact that the enterprises of the metallurgical complex export $95 \%$ of their products, i.e. for the construction industry that is developing now, and in general for the industry, domestic metal products are not used. The share of the metallurgical complex in the country's total export volume is $35 \%$.

As shown in table 2, in 2018, there were 101 enterprises operating in the ferrous metallurgy, and during the period under review, there was a 2 -fold increase in production volumes in value terms.

Table 2. Dynamics of economic indicators in the ferrous metallurgy of Kazakhstan

\begin{tabular}{|c|c|c|c|c|c|}
\hline & 2014 & 2015 & 2016 & 2017 & 2018 \\
\hline Number of enterprises and production facilities & 88 & 94 & 106 & 105 & 101 \\
\hline The volume of industrial production, mln. tenge & 759242 & 773549 & 1134246 & 1535768 & 1681332 \\
\hline $\begin{array}{l}\text { Industrial production index, as a percentage of } \\
\text { the previous year }\end{array}$ & 108,9 & 100,9 & 103,6 & 106,2 & 98,3 \\
\hline Profit (loss) before tax, mln. tenge & 66332 & -35274 & 327476 & 474226 & 312205 \\
\hline Profitability, as a percentage & 7,6 & $-2,6$ & 42,0 & 28,2 & 17,2 \\
\hline $\begin{array}{l}\text { Producer price index, as a percentage of the } \\
\text { previous year }\end{array}$ & 111,1 & 95,7 & 157,2 & 120,4 & 112,9 \\
\hline Investments in fixed assets, mln. tenge & 145767 & 99532 & 101388 & 59703 & 121005 \\
\hline as a percentage of the previous year & 87,5 & 66,4 & 97,4 & 157,7 & 186,8 \\
\hline
\end{tabular}

The variability of profitability, especially in 2015 , is explained by global market trends, since almost the entire volume is exported.

The same trend led to negative profitability of non-ferrous metallurgy (Table 3) (World Steel in Figures, 2020).

Table 3. Dynamics of economic indicators in Kazakhstan's non-ferrous metallurgy

\begin{tabular}{|l|c|c|c|c|c|}
\hline & 2014 & 2015 & 2016 & 2017 & 2018 \\
\hline Number of enterprises and production facilities & 36 & 41 & 45 & 55 & 61 \\
\hline The volume of industrial production, mln. tenge & 1145815 & 1360432 & 2239522 & 2531768 & 2921929 \\
\hline $\begin{array}{l}\text { Industrial production index, as a percentage of the } \\
\text { previous year }\end{array}$ & 96,2 & 123,4 & 108,5 & 106,3 & 105,4 \\
\hline Profit (loss) before tax, mln. tenge & 89451 & -7120 & 517900 & 578624 & 707627 \\
\hline Profitability, as a percentage & 7,1 & $-0,5$ & 23,7 & 24,0 & 26,0 \\
\hline $\begin{array}{l}\text { Producer price index, as a percentage of the previ- } \\
\text { ous year }\end{array}$ & 109,3 & 104,4 & 149,4 & 114,6 & 108,1 \\
\hline Investments in fixed assets, mln. tenge & 149947 & 218395 & 210201 & 127471 & 147944 \\
\hline as a percentage of the previous year & 111,1 & 142,2 & 91,8 & 58,1 & 111,1 \\
\hline Note - compiled by the author on the basis (World Steel in Figures, 2020) & & \\
\hline
\end{tabular}

In general, in the dynamics it should be noted a sufficient increase in the number of enterprises in the industry, an almost 3-fold increase in the volume of production in value terms.

Ferrous metallurgy occupies a priority place in the development of the mining and metallurgical complex. Kazakhstan ranks eighth in the world in terms of iron ore reserves (after Russia, Ukraine, the USA, Australia, Brazil, Canada and South Africa). Its share in world reserves is $6 \%$. In addition to significant reserves, another advantage of Kazakhstan's iron ore is its fairly high quality: out of 8.7 billion tons of iron ore, $73.3 \%$ of the reserves are easily extracted. In addition the country is relatively well provided with reserves of iron easily rich ores: it is more than 50 years old. 
A general analysis of the state of production in the metallurgical complex of the Republic of Kazakhstan allows us to conclude that at present:

- there is practically no industrial production of science-intensive, high-tech, special materials and alloys for the development of modern production in the country;

- the required range of rolled products and metal products is not produced for machine-building, oil and gas, mining and metallurgical, light, food and other industries, construction industry, heavy engineering and shipbuilding;

- there are no industrial production of materials and metal products based on the latest technologies powder metallurgy, electrometallurgy, electroplating, new foundry and chemical technologies, etc.;

- secondary resources of metals are not used efficiently, the balance of which is not fully taken into account.

In general, the domestic mining and metallurgical complex is characterized by relatively outdated technologies of the metallurgical limit and high physical wear and tear of fixed assets, which is reflected in the level of energy consumption, labor intensity and material consumption of production and determines the lag in technical development from its competitors..

This state, on the one hand, due to dumping prices, allows us to maintain high demand for metal products, but on the other hand, it contributes to slowing down scientific and technological progress, reducing competitiveness in world markets, and reducing the efficiency of metallurgy as a whole by reducing factor competitive advantages.

On the whole, some large enterprises of ferrous and nonferrous metallurgy have managed to adapt to new market conditions and are now one of the influential factors in the growth of the regional economy. The existing integration formations have a positive impact on the formation of new industries in metallurgy (in particular, the production of coking coal in the Karaganda basin, a fairly strong iron ore base is owned by "Arcelor Mittal Temirtau» JSC), the problems of development of consumer industries: machine building and metalworking, construction and agro-industrial complex, etc., the presence of bottlenecks in production chains, etc.

The level of consumption of metal products per capita in Kazakhstan is significantly lower than in the developed countries of the world, which gives grounds for optimistic forecasts of the development of domestic demand for metal products. In this regard, it is necessary to focus primarily on domestic markets. However, it should be noted that the possibilities for increasing steel production at the expense of the existing domestic capacities are practically exhausted. This allows us to state that the period of development of the industry based on a more complete use of existing capacities is generally over. The investment resources of the industry are largely determined by the profitability of production, which in turn depends on the level of prices for metal products. Therefore, for the prospects for the development of the domestic metallurgical industry, an unbiased assessment of the price situation on the metal products market is of great importance. A further increase in steel production is impossible without significant investments in the construction of new steel-making facilities and modernization of production.

\section{Discussions}

In Kazakhstan, the actual minerals and products of their primary processing (including metallurgical treatment) make up about $80 \%$ of GDP. This determines the great importance of the mineral resource complex and its specific role in the formation of industrial policy.

Based on this, priority directions of restructuring of the metallurgical industry of the economy follow, which plays a major role in improving the manufacturability of production, as the main supplier of ferrous, non-ferrous and rare metals and products from them. It is necessary to take into account the fact that the construction and reconstruction of metallurgical plants requires one-time large investments. During the period of the plant's design cycle, the composition and structure of raw materials change, and part of the equipment becomes morally and physically obsolete. In such a situation, even the preservation of technological indicators for the extraction of metals and their quality is a rather difficult task. In this regard, innovative activities in the field of metallurgy restructuring primarily include:

- Involvement in processing of new types of raw materials (often of inferior quality) and technogenic formations of both our own and enterprises of other industries;

- mastering new technologies and equipment, including resource and energy saving processes and processing modes;

- creation of new types of marketable products; 
- improving the environmental safety of processes and the use of new treatment equipment.

In addition, the growing world globalization, as well as the formation of integrated metallurgical consortia among the world's largest metal producers, are of great importance for the national metallurgy. Hence, a new industrial policy in the development of the metallurgical complex of Kazakhstan should be formed taking into account both its links with the world economy and systemic risks caused by the disproportions in the existing sectoral structure of the metallurgical industry. This implies a combination of effective management of metal ores and their metallurgical treatments with the desire to expand the scale of the national economy by moving to a greater variety of metallurgical products and entering new markets. Movement along this path is impossible without a versatile technological, organizational and managerial renewal.

In Kazakhstan, in recent years, efforts have been made at the state level to work out a development strategy for the domestic ferrous metallurgy. However, the existing strategic developments do not pay sufficient attention to the organizational factors of the industry's competitiveness, do not take into account the trends of the post-industrial economy. As guidelines for organizational transformations in the industry, it is proposed to consider, in particular, the following:

- entry of even medium and small metallurgical enterprises with promising niches into clusters or business groups of metallurgical or machine-building composition;

- the formation of integrated structures from metallurgical enterprises of various profiles and dealer networks, which will allow consumers to purchase all the necessary metal products in one place. In the long term, the needs for a wide range of structural materials should be met in this way;

- accelerated development of a service for high-quality rolled metal processing according to customer requirements within the framework of the integration of metal suppliers and its consumers;

- development of cooperation between leading metallurgical companies, including joint measures to support domestic heavy engineering, joint research projects.

Summarizing the above, the following factors of the competitiveness of metallurgical production, differentiated at the macro and micro levels, can be distinguished (Figure 1).

Macroeconomic level

\begin{tabular}{|c|}
\hline $\begin{array}{c}\text { Economic policy of the country (subsidies, bene- } \\
\text { fits to national metal producers) }\end{array}$ \\
\end{tabular}

The state of the regulatory and technical base (harmonization of domestic standards and rules with international ones)
Microeconomic level

The level of development of information technology (creation of an information base for exporters and importers)

The cost of resources (energy resources, consumption of metal, labor, tariffs for the transpor-

Scientific and technical development potential of 4 th-5th treatments

Geographical, political and economic position of the country (investment climate in the country)

The state of the financial system (exchange rate and stability of the national currency)

Foreign economic strategy of the country (in particular, participation in the WTO)

tation of goods, etc.)

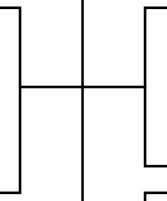

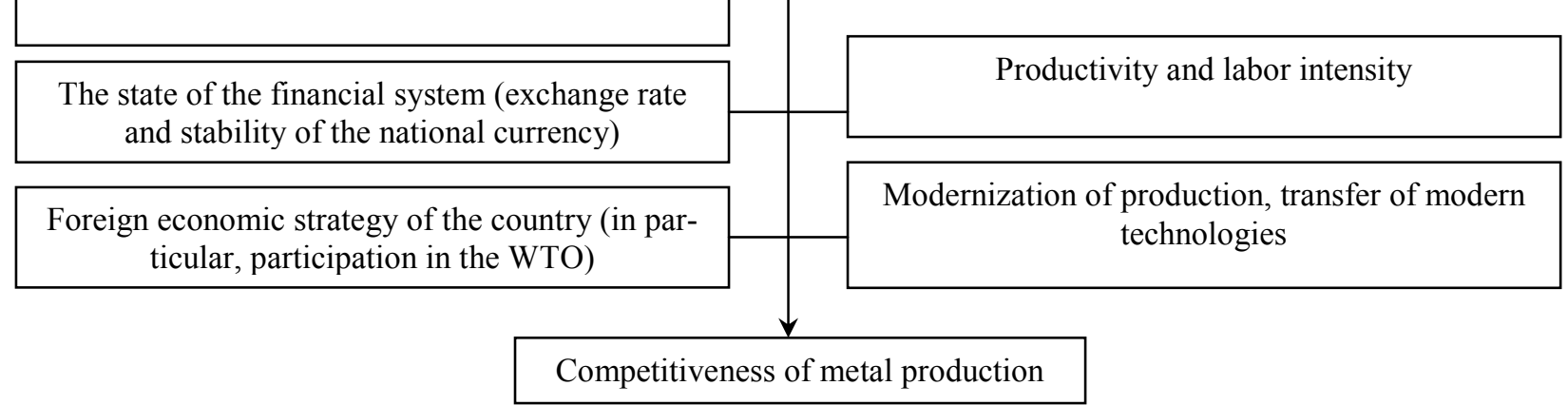

Figure 1. Macro-and micro-economic factors of competitiveness of steel products

Note-compiled by authors 
In the near future, one of the factors of economic development, increasing competitiveness and strengthening the export potential of domestic producers is expected to increase the volume of capital investments. An additional source of stimulating the development of export-oriented industries should be joint (state and non-state) financing of investment projects using international leasing.

Achieving high competitiveness of industrial producers should be a priority of the country's economic policy, since their successful functioning is a necessary condition for national security, improving the living standards of the country's population, saturating the domestic market and ensuring successful integration into the global economic process.

The general activities of developed country governments in this regard are:

- implementation of a unified state policy to improve competitiveness, using economic, legal and political means;

- support of priority areas of development of the metallurgical industry and promotion of structural changes in the mining and metallurgical complex;

- implementation of state support for national metal producers and protection of the domestic market, including measures for marketing support of domestic producers ' products;

- promotion of market infrastructure development (creation of a competitive environment, introduction of international certification, introduction of harmonized quality assessment systems and standards).

\section{Conclusions}

In order to maintain and increase the positive production and economic dynamics of the development of the metallurgical plant in Kazakhstan, increase the competitiveness of the manufactured metal products, increase export earnings, it is necessary to concentrate financial and technical resources, diversify production within this production along the full cycle technological chain (mining, dressing, metallurgical treatment), expansion of domestic and foreign sales markets.

In metallurgy, the planning and forecasting horizon has a 7-10 year perspective. These horizons are primarily associated with high investment costs. Organization of the 4th-5th treatment in metallurgy is capital-intensive projects that business is clearly not able to handle without very large investments in infrastructure.

The modernization of production, increasing the competitiveness of products, the search for new promising markets and consumers require not only active government support in developing a balanced industrial, foreign trade and tax policy, but also significant investment resources.

Achieving these goals of the state policy for the development of metallurgy requires the implementation of a set of measures to create a favorable investment climate in the country, support investment initiatives in the market sector of the economy, and create legislative and institutional conditions for the economic activities of private investors that are adequate to modern market requirements.

In connection with the above, the main principles of state policy will be:

- in the field of creating a favorable investment climate in metallurgy:

- strengthening the role of the state as a guarantor of maintaining a favorable and predictable regulatory regime for the economic activity of domestic and foreign investors; publicity of the state investment policy;

- creation of equal competitive conditions for economic activity for all investors, regardless of the form of ownership, contributing to the efficient allocation of capital and sustainable economic development;

- introduction of effective legislative and practical mechanisms to protect the interests and rights of investors in the implementation of investment projects;

- liberalization of the market for investment projects by simplifying the approval procedures and obtaining permits for their development and implementation;

- ensuring the opportunity for investors to obtain reliable information about organizations in order to analyze and select investment objects;

- assistance in the formation of a modern institutional infrastructure of the investment market, ensuring the effective transformation of savings of the national economy into investments in metallurgical production.

- in the field of public investment:

- strengthening the social orientation of investment activities in the country, the unconditional priority of investments in solving problems of fundamental and applied science in the field of metallurgy; 
- openness and predictability of the state investment policy, stimulation of attracting capital from the non-state sector for solving the priority tasks of metallurgy development;

- prioritization of state support for strategically important infrastructure facilities for the country, contributing to an innovative and technological breakthrough in metallurgy.

- in the field of supporting investment activities of the private sector of the economy:

- creating conditions for increasing the investment potential of metallurgical enterprises in Kazakhstan by reducing the tax burden, improving the depreciation policy;

- liberalization of foreign trade and tax regime for the import to Kazakhstan of modern technological equipment required for the modernization of existing metallurgical enterprises.

In order to effectively finance the modernization processes in the metallurgical industry aimed at the development of 4th-5th treatment, it is necessary to consider mechanisms that facilitate the flow of financial capital from the main sources of investment in this sector of the economy

Thus, for the sustainable and dynamic development of metallurgy, it is necessary to increase the efficiency of the financial intermediation system, designed to ensure the accumulation of temporarily free funds of individuals and legal entities and the transformation of savings into investments.

\section{Complementary Data}

The research is funded by the grant of the Committee of science of the Ministry of education and science of the Republic of Kazakhstan AP08053430 «Strategy of technological development of MMC of Kazakhstan: PPP as a driver of investment growth and foresight positioning in the context of industry 4.0».

\section{References}

Breunig M., Kelly R., Mathis R., Wee D. (2016) Getting the most out of Industry 4.0 // www.mckinsey.com. Retrieved from https://www.mckinsey.com

Byun, J., Sung, T.-E., \& Park, H.-W. (2017). Technological innovation strategy: how do technology life cycles change by technological area. Technology Analysis \& Strategic Management, 30(1), 98-112. doi: doi.org/10.1080/09537325.2017.1297397

Djelic M.-L., Quack S. 2018) Globalization and Business Regulation. Annual Review of Sociology, 44(1), 123-143 doi.org/10.1146/annurev-soc-060116-053532

Dotsenko E., Ezdina N., Mudrova S. (2019) Zero Waste Technologies and Solution of Economic and Environmental Problems of Sustainable Development. E3S Web of Conferences 105. doi.org/10.1051/e3sconf/201910502008

ElGindi T. (2017) Natural resource dependency, neoliberal globalization, and income inequality: Are they related? A longitudinal study of developing countries (1980-2010). Current Sociology, 65(1), 21-53. doi.org/10.1177/0011392116632031

Exports of steel products such as bars, billets, blooms, coils, rails, sections, sheets, slabs, etc. Source: Steel Statistical Yearbook, 2019 Retrieved from: https://www.worldsteel.org/.

Gajdzik B. (2019) Steel industry 4.0 in the perspective of forecasted quantities of steel production in the world. Scientific papers of the Silesian university of technology. Retrieved from http://dx.doi.org/10.29119/16413466.2019.134.2.

Imports of steel products such as bars, billets, blooms, coils, rails, sections, sheets, slabs, etc. Source: Steel Statistical Yearbook, 2019 https://www.worldsteel.org/

Ivantera V.V. (2017). Strukturno-investitsionnaya politika v tselyakh ustoychivogo rosta i modernizatsii ekonomiki [Structural and investment policy for sustainable growth and modernization of the economy] Moskva [Moscow]. IPN RAN [in Russian]..

Jiaa X., Dominic C.Y.Foo, Raymond R.Tan, Zhiwei Li (2017) Sustainable development paths for resource-constrained process industries. Resources, Conservation and Recycling, 119, 1-3. doi.org/10.1016/j.resconrec.2016.11.004

Liu W., Dunford M. (2016) Inclusive globalization: unpacking China's Belt and Road Initiative. Area Development and Policy, 1,(3), 323-340. doi.org/10.1080/23792949.2016.1232598

Massa, I. (2015). Technological Change in Developing Countries: Trade-Offs Between Economic, Social and Environmental Sustainability. Background paper prepared for the 2015 Industrial Development Report. Retrieved from URL: https://www.unido.org/

Radim Lenort et al. (2017) Comparative Study of Sustainable Key Performance Indicators in Metallurgical Industry. Middle pomeranian scientific society of the environment protection. 19, 36-51.

Satybaldin AA. (2016) Realnyi sektor ekonomiki Kazakhstana: industrialno-tekhnologicheskie preobrazovaniia: koll. monohrafiia [The real sector of the economy of Kazakhstan: industrial and technological transformations: coll. monograph]. Almaty: IJe KN MON RK [in Russian]..

Sung Park H., Kim D. (2019) Efficiency Analysis of East Asian Zinc Smelters and the Effects of Capacity and Bonus Zinc on Efficiency. Journal of Open Innovation: Technology, Market, and Complexity. 5(4), 1-14. Retrieved from http://dx.doi.org/10.3390/joitmc5010004 
Sustainable Steel: Indicators 2019 and the steel supply chain. Retrieved from: https://www.worldsteel.org/

The Asian century is set to begin (2019). Financial Times. Retrieved from http://www.ft.com/content/520cb6f6-295811e9-a5ab-ff8ef2b976c7

Wang, W.Y., Zheng, C.X. and Liu, P. (2016) A Study on Overseas Investment Opportunities of Chinese Iron and Steel Enterprises from the Perspective of Globalization Strategy. Open Journal of Social Sciences, 4, 74-86. Retrieved from: http://dx.doi.org/10.4236/jss.2016.45011

World Steel in Figures 2020. Retrieved from: https:/www.worldsteel.org/

\section{А.Қ. Қабдыбай, Н.Д. Кенжебеков, Д.И.Сыздыкова, Д.Н. Улыбышев, Е.Б. Жайлауов \\ Қазақстанның кен-металлургиялық кешенінің технологиялық дамуының мемлекеттік саясатының бағыттары}

\section{Aндатnа}

Maқ̧саты: Отандық металлургиялық кешендегі жоғары технологиялық өндірістің дамуы мен оны модернизациялауға бағытталған, Қазақстанның технологиялық саясатының алғы шарттарын анықтау.

Әдісі: зерттеуді жүргізу кезінде жүйелік талдау, қосымша ақпараттарды жинау, мақсаттарды құрылымдау әдістері қолданылды.

Қорытынды: Республиканың экономикалық потенциалындағы металлургиялық кешеннің жағдайын бағалау мен рөлін анықтау негізгі нәтижелер болып табылады, дамудың алғы шарттарын анықтау негізінде Қазақстанның металлургиясын құрылымдық-технологиялық реформалау бойынша нұсқаулар берілді. Сондықтан, ішкі нарықтағы металөнімдерінің күнделікті қолданылуы және металлургиялық кәсіпорындардың өткізу құрылымында экспорттық құрамның жоғары үлесі кезіндегі отандық кәсіпорындарда сортты кеңейтуге және жаңа материалдарды меңгеруге күшті мотивация жоқ.

Тұжырымдама: Біздің ойымызда, жақын арада бар инновациялық жүйеден жаңа технологияларды күту қажет емес, технологиялар трансферті қалыптасқан контрагенттерге байланысты қиын: күрделі трансұлттық корпорациялардың шетелдік инвестициялары шикізат базасын дамытуға және өндіру күштерін арттыруға бағытталған. Осыған байланысты, мемлекеттік саясат ең алдымен табиғи ресурстарды пайдаланудың кешенділігі мен тиімділігіне болуы керек.

Әрекет етуші кәсіпорындардың өндірістік күштерін толық пайдалануды қамтамасыз етуге арналған істен шыққан кендерді қалпына келтіру жолдарының бірі кедей баланстан кендерді эксплуатациялауға тарту, сондай-ақ бұрын істеген участкелерді консервациялау және шығынға жабылған кендерді алу.

Kiлm сөздер: тау-металлургиялық кешен, металлургиялық қайта өндіру, модернизация, минералды-шикізат ресурстарын тиімді пайдалану, технологиялық саланың бәсеке қабілеттілігі, технологиялық құрылыс.

\section{А.К. Кабдыбай, Н.Д. Кенжебеков, Д.И. Сыздыкова, Д.Н. Улыбышев, Е.Б. Жайлауов}

\section{Направления государственной политики технологического развития горно-металлургического комплекса Казахстана}

\section{Аннотация}

Цель: Цель заключается в определении приоритетов технологической политики Казахстана, направленных на модернизацию и развитие высокотехнологичного производства в отечественном металлургическом комплексе.

Meтoдbl: При проведении исследования использованы методы системного анализа, сбора вторичной информации и структуризации целей.

Результаты: В качестве основных результатов следует выделить оценку состояния и определения роли металлургического комплекса в экономическом потенциале республики, на основе определения приоритетов развития были даны рекомендации по структурно-технологическому реформированию металлургии Казахстана. Необходимо отметить, что при высокой доле экспортной составляющей в структуре сбыта металлургических предприятий и постоянном дефиците металлопродукции на внутреннем рынке у отечественных предприятий нет сильной мотивации заниматься расширением сортамента и освоением новых материалов.

Bblводbl: По нашему мнению, прорывных технологий от существующей инновационной системы в ближайшее время не стоит ожидать, трансферт технологий затруднен в силу сложившихся контр- 
агентов: иностранные инвестиции крупных транснациональных корпораций направлены на развитие сырьевой базы и увеличение добывающих мощностей. В этой связи государственная политика должна быть направлена, в первую очередь, на комплексность и рациональность использования природных ресурсов. Для обеспечения более полного использования производственных мощностей действующих предприятий одним из путей восполнения выбывающих мощностей является вовлечение в эксплуатацию бедных забалансовых руд, а также повторная разработка ранее отработанных участков, расконсервация охранных целиков и извлечение списанных в потери руд.

Ключевые слова: горно-металлургический комплекс, металлургический передел, модернизация, рациональное использование минерально-сырьевых ресурсов, технологическая политика, конкурентоспособность металлургической отрасли, технологический уклад.

\section{References}

Breunig M., Getting the most out of Industry 4.0 [Text] / Breunig M., Kelly R., Mathis R., Wee D. — Режим доступа: https://www.mckinsey.com

Byun, J. Technological innovation strategy: how do technology life cycles change by technological area. [Text] / Byun, J., Sung, T.-E., \& Park, H.-W. // Technology Analysis \& Strategic Management. — 2017. — № 30(1). P. 98-112. — Режим доступа: // https://doi.org/10.1080/09537325.2017.1297397

Djelic M.-L. Globalization and Business Regulation [Text] / Djelic M.-L., Quack S. // Annual Review of Sociology. 2018. — № 44(1). — P. 123-143. — Режим доступа: https://doi.org/10.1146/annurev-soc-060116-053532

Dotsenko E. Zero Waste Technologies and Solution of Economic and Environmental Problems of Sustainable Development [Text] / Dotsenko E., Ezdina N., Mudrova S. // E3S Web of Conferences. — 2019. — 105(1). — P. 1-6. — Режим доступа: https://doi.org/10.1051/e3sconf/201910502008

ElGindi T. Natural resource dependency, neoliberal globalization, and income inequality: Are they related? A longitudinal study of developing countries (1980-2010) [Text] / ElGindi T. // Current Sociology. — 2017. — № 65(1).P. 21-53. Режим доступа: https://doi.org/10.1177/0011392116632031

Exports of steel products such as bars, billets, blooms, coils, rails, sections, sheets, slabs, etc. [Text] Source: Steel Statistical Yearbook, 2019. - Режим доступа: https://www.worldsteel.org/.

Gajdzik B. Steel industry 4.0 in the perspective of forecasted quantities of steel production in the world [Text] / Gajdzik B. // Scientific papers of the Silesian university of technology. — 2019. — № . 134. Режим доступа: http://dx.doi.org/10.29119/1641-3466.2019.134.2.

Imports of steel products such as bars, billets, blooms, coils, rails, sections, sheets, slabs, etc. [Text] Source: Steel Statistical Yearbook, 2019.- Режим доступа: // https://www.worldsteel.org/

Jiaa X, Sustainable development paths for resource-constrained process industries [Text] / Xiaoping Jiaa, Dominic C.Y.Foo, Raymond R.Tan, Zhiwei Li // Resources, Conservation and Recycling. — 2017. — № 119. — P. 1-3. — Режим доступа: https://doi.org/10.1016/j.resconrec.2016.11.004.

Liu W. Inclusive globalization: unpacking China's Belt and Road Initiative [Text] / Liu W., Dunford M. // Area Development and Policy. - 2016. - № 1(3). - P. 323-340. - Режим доступа: https://doi.org/10.1080/23792949.2016.1232598

Massa, I. Technological Change in Developing Countries: Trade-Offs Between Economic, Social and Environmental Sustainability. Background paper prepared for the 2015 [Text] / Industrial Development Report. — 2015. Режим доступа: https://www.unido.org/api/opentext/documents/download/9928078/unido-file-9928078

Radim Lenort. Comparative Study of Sustainable Key Performance Indicators in Metallurgical Industry [Text] / Radim Lenort // Middle pomeranian scientific society of the environment protection. - 2017. — № 19. - P.36-51.

Sung Park H. Efficiency Analysis of East Asian Zinc Smelters and the Effects of Capacity and Bonus Zinc on Efficiency [Text] / Sung Park H., Kim D. // Journal of Open Innovation: Technology, Market, and Complexity. — 2019. — № . 5(4). — P.1-14. — Режим доступа: http://dx.doi.org/10.3390/joitmc5010004

Sustainable Steel: Indicators 2019 and the steel supply chain. [Text]. - Режим доступа: https://www.worldsteel.org/

The Asian century is set to begin [Text] // Financial Times. - 2019. - Режим доступа: https://www.ft.com/content/520cb6f6-2958-11e9-a5ab-ff8ef2b976c7

Wang, W.Y. Study on Overseas Investment Opportunities of Chinese Iron and Steel Enterprises from the Perspective of Globalization Strategy [Text] / Wang, W.Y., Zheng, C.X. and Liu, P. // Open Journal of Social Sciences. — 2016. — № . 4. - P.74-86. - Режим доступа: http://dx.doi.org/10.4236/jss.2016.45011

World Steel in Figures 2020 [Text]. — Режим доступа: https://www.worldsteel.org/

Сатыбалдин А.А. Реальный сектор экономики Казахстана: индустриально-технологические преобразования: колл. моногр. [Текст] / А.А. Сатыбалдин. — Алматы: ИЭ КН МОН РК, 2016. — 364 с.

Ивантера В.В.Структурно-инвестиционная политика в целях устойчивого роста и модернизации экономики [Текст] / В.В. Ивантера. — М.: ИНП РАН, 2017. — 34 с. 